\title{
Development of Tomato (Lycopersicum esculentum Mill.) Roots in Every Growth Stage in Flooding Conditions
}

\author{
Rabiatul Jannah', Julianthy Diana Natalia1, and Odit Ferry Kurniadinata1, \\ ${ }^{1}$ Faculty of Agriculture, Universitas Mulawarman, Samarinda, Indonesia \\ Jl. Kuaro, Gn. Kelua, Kec. Samarinda Ulu, Kota Samarinda, Kalimantan Timur 75119 \\ *Corresponding author: odit.ferry@faperta.unmulac.id
}

\section{ARTICLE HISTORY}

Received : 10 February 2019

Revised : :12 March 2019

Accepted : 22 April 2019

\section{KEYWORDS}

Flooding simulation

Growth

Root length

Soil aeration

Water stress

Water saturation

\begin{abstract}
Flooding is a natural phenomenon that often occurs in the rainy season arrives with high rainfall This phenomenon give an effect to plant growth if it occurs in agricultural areas. This research was carried out at Samarinda, Indonesia. This study uses a completely randomized design non factorial, consists of 4 lavels ie; 4 hours height level 50\% flooding (J1), 8 hours height level 50\% flooding (J2), 4 hours height level 100\% flooding (J3), 8 hours height level 100\% flooding (J4), carried out with 4 repetitions. Flooding simulation is carried out 5 times in each growth phases of tomato plants. The data analysis used Anova. If the variance is significantly different, then followed by the LSD (Least Significance Different) at 5\%. The results showed that simulation of flooding with times 8 hours height level $50 \%$ flooding had a morederate negative effect on tomato plants. The flooding simulation with times 8 hours height level 100\% flooding gives the highest negative effect on tomato plants and the root, due to excess water requirements so that plants cannot meet needs of the plants.
\end{abstract}

This is an open access article under the CC-BY-SA license.

\section{INTRODUCTION}

Flooding is a natural phenomenon that often occurs when the rainy season arrives with high rainfall, which can have an effect on the growth of annual crops in lowland areas which generally tend to be close to the river flow. According to Pezeshki (2006) and Lu et al. (2004), agricultural land in the lowlands is very at risk of flooding when the rainy season arrives or even in certain months or in the wet months. At the time of flooding, it can pose a severe threat to plants, especially at the roots of plants that are most susceptible to flooding and the first suffer from lack of oxygen (Armstrong, 1987; Huang et al. 1997; and Pezeshki, 2001)

Roots have an important role in nutrient uptake and plant water for the growth and maintenance of functional root systems. During plant growth, roots have a role to maintain their function when flooding conditions occur. Some root systems in certain plants are able to survive in taking micro nutrients in water and host microorganisms in water (Armstrong, 1987; Harjadi et al., 1988; and Besset et al., 2001). However, for horticulture commodities, some cannot survive in flooding conditions, because the risk in the growth and development of roots in the soil when flooding occurs (Bandi et al., 2014).

Tomato plants are horticultural commodities that have high economic value but require serious handling in an effort to improve the yield and quality of tomatoes (Gould, 1974; Rudich et al., 1986; and Kurniadinata et al., 2016). According to Cahyono (1998), the water demand for cultivating tomato plants is not too much, but it cannot be less of water. Giving excessive water to the tomato plant area can cause tomatoes to grow elongated, unable to absorb nutrients, and susceptible to disease. Furthermore, the less water in tomato plantations can disrupt plant growth at the initial stage, resulting in broken fruit in the fruit, and can cause the flowers loss if water shortages occur during the flowering period. Based on the problems described above, a study was conducted to determine the effect of flooding on performance and development of tomato root rooting on flooding condition.

\section{METHOD}

\subsection{Time and Place}

This research was conducted from April to June 2018, in Sempaja Utara, Samarinda, Indonesia.

\subsection{Materials and Tools}

The materials used in this study were F1 tomato: servo varieties, chicken manure, leaf fertilizer, fuel husk, soil, water, $40 \mathrm{~cm} \times 50 \mathrm{~cm}$ polybags, and label paper. The tools 
used, the nursery, the plot of land dividing board, stationery, paranet/tarpaulin, ruler, calculator, water hose, documentation tool, measuring instrument for soil $\mathrm{pH}$ and $\mathrm{pH}$ of water, soil sieve, water pipe and rope raffia.

\subsection{Method}

This study uses a completely randomized design (CRD) of one factor, namely the condition of the planting media giving flooding (J) consists of 4 levels, namely: 4 hours with a level of $50 \%$ flooding (J1), 8 hours with an altitude of $50 \%$ flooding (J2) , 4 hours with a height level of $100 \%$ flooding (J3), 8 hours with an altitude level of $100 \%$ flooding (J4). Each treatment was repeated 4 times with 4 plants per replicate so that there were 64 plants.

\subsection{Data Collection}

The data collected in the study was obtained from the observation variables as follows. After 28 days of growing tomato plants, the plants are then given a day of flooding conditions. The provision of flooding and observation is continued during the growth of the vegetative phase of the plant until the growth of the generative phase or the flowering phase of tomato plants, continued from the flowering phase to the fertilization phase and then continued until the final harvest phase of tomato plants. Observations on tomato roots were carried out every 14 days and then removed in each phase after being given flooding with root observation criteria: root length, number of roots (vertical roots and horizontal roots on the grid board), root length binding to soil diameter, number of adventitious roots, weight wet root, root dry weight.
The total root length formula uses the Line Intersect Marsh method (Tennant, 1975):

$$
R=\frac{11}{14} x N x G U
$$

Information :

$$
\begin{array}{ll}
\mathrm{R} & : \text { Root }(\mathrm{cm}) \\
\mathrm{N} & : \text { Number of intercepts } \\
\mathrm{GU} & : \text { Grid Unit }(1 \mathrm{~cm})
\end{array}
$$

\subsection{Data Analysis}

The data collected was carried out by variance with the $\mathrm{F}$ test. If the variance was significantly different, then to compare the average treatment continued with the Smallest Significant Difference Test (LSD) at the level of $5 \%$.

\section{RESULTS AND DISCUSSION}

\subsection{Effect of Flooding on the Growth and Development of Tomato Plants Root in Vegetative Phase}

Observation of tomato roots in vegetative phase was carried out once, at 41 days after planting (DAP). Root observation criteria were: total length of root, root length, adventitious root, root length binding to soil, root wet weight, root dry weight. The results of processed

\begin{tabular}{|c|c|c|c|c|c|c|}
\hline Treatment & $\begin{array}{l}\text { Total Root } \\
\text { Length (TRL) }\end{array}$ & $\begin{array}{l}\text { Tomato Plant } \\
\text { Root Length }\end{array}$ & $\begin{array}{l}\text { Number of } \\
\text { Adventive Roots }\end{array}$ & $\begin{array}{l}\text { The Diameter of Soil } \\
\text { binded by root }\end{array}$ & $\begin{array}{l}\text { Tomato Root Wet } \\
\text { Weight }\end{array}$ & $\begin{array}{l}\text { Tomato Root Dry } \\
\text { Weight }\end{array}$ \\
\hline & $\mathrm{cm}$ & $\mathrm{cm}$ & Root & $\mathrm{cm}$ & $\mathrm{g}$ & $\mathrm{G}$ \\
\hline $\mathrm{J} 1$ & 1897.80 & 22.60 & $6.00 \mathrm{~b}$ & $5.55 a$ & 8.75 & 1.67 \\
\hline $\mathrm{J} 2$ & 2144.40 & 24.12 & $8.75 a$ & $3.70 \mathrm{~b}$ & 10.20 & 1.94 \\
\hline $\mathrm{J} 3$ & 1544.30 & 22.75 & $8.50 a$ & $5.75 a$ & 5.38 & 1.41 \\
\hline $\mathrm{J} 4$ & 1524.80 & 20.17 & $8.00 a$ & $4.50 \mathrm{ab}$ & 5.51 & 1.13 \\
\hline Sig. & Ns & ns & $*$ & $*$ & ns & Ns \\
\hline
\end{tabular}
observational data can be seen in the Table 1.

Table 1. Effect of Flooding on Total Root Length (LRV) of Tomato Plants, Tomato Plant Root Length, Number of Adventive Tomato Roots, Diameter of Soil binded by root, Wet Weight and Dry Weight of Tomato Plant Roots (41 DAP)

Note : J1= 4 hours of 50\% flooding level; J2= 8 hours of 50\% flooding level; J3= 4 hours of 100\% flooding level; J4= 8 hours of $100 \%$

flooding level.

Flooding condition in the vegetative phase for two weeks from 24 days after planting (DAP) to 40 DAP with five times flooding application gives a variety of influences on number of adventive roots and root length binding to soil diamater.

The results showed that the application of flooding to tomato plants affected the growth and development of tomato roots. Giving flooding for 8 gives the same effect on all treatments both $50 \%$ and $100 \%$ flooding applications. This shows that when exposed to flooding, plants will initiate root growth, the longer the time of flooding, the tomato plants will respond to initiate the form of adventive root growth in response to stress inundation. However, the results of the study also showed that application of flooding for 4 hours also had the same effect as 8 hours if it was exposed to $100 \%$ flooding.

The flooding treatment also influences the diameter of the soil that can be bound by the roots of the tomato plant. This is related to an increase in the number of adventitious roots. The more adventitious roots that are formed, the greater the diamter of soil that can be bound by the roots. This mechanism shows that roots grow and develop in groups around the base of the stem as a mechanism of adaptation of the given flooding stress, and 
avoid damage to plant tissue and death. Yulianti et. al, (2015) reported that the treatment of flooding for long times results in a delays in the transport system that occurs in the supply of the soil when flooding occurs.

\subsection{Effect of Flooding on the Growth and Development of Tomato Plants Root in Generative Phase}

Table 2. Effect of Flooding on Total Root Length (LRV) of Tomato Plants, Tomato Plant Root Length, Number of Adventive Tomato Roots, Diameter of Soil binded by root, Wet Weight and Dry Weight of Tomato Plant Roots (55 DAP)

\begin{tabular}{|c|c|c|c|c|c|c|}
\hline Treotmont & $\begin{array}{l}\text { Total Root Length } \\
\text { (TRL) }\end{array}$ & $\begin{array}{c}\text { Tomato Plant Root } \\
\text { Length }\end{array}$ & $\begin{array}{c}\text { Number of Adventive } \\
\text { Roots }\end{array}$ & $\begin{array}{l}\text { The Diameter of Soil } \\
\text { binded by root }\end{array}$ & $\begin{array}{l}\text { Tomato Root } \\
\text { Wet Weight }\end{array}$ & $\begin{array}{l}\text { Tomato Root } \\
\text { Dry Weight }\end{array}$ \\
\hline & $\mathrm{Cm}$ & $\mathrm{cm}$ & root & $\mathrm{Cm}$ & g & g \\
\hline $\mathrm{J} 1$ & 2888.00 & 41.00 & 10.25 & 13.50 & 15.13 & 2.91 \\
\hline $\mathrm{J} 2$ & 3089.40 & 35.75 & 10.50 & 12.00 & 20.17 & 2.52 \\
\hline $\mathrm{J} 3$ & 3145.90 & 41.66 & 9.50 & 12.12 & 15.40 & 3.48 \\
\hline $\mathrm{J} 4$ & 2782.90 & 43.55 & 10.25 & 11.25 & 19.05 & 3.83 \\
\hline Sig. & Ns & Ns & ns & Ns & ns & ns \\
\hline
\end{tabular}

Note: $\mathrm{J} 1=4$ hours of $50 \%$ flooding level; $\mathrm{J} 2=8$ hours of 50\% flooding level; J3= 4 hours of $100 \%$ flooding level; $\mathrm{J} 4=8$ hours of $100 \%$ flooding level.

Flooding condition in the generative phase, from 42 DAP to 54 DAP with five times flooding application did not give influences for all variable including; total root length, root display, adventitious roots, root length binding to soil diamater, root wet weight, root dry weight.

The results showed that when entering the generative phase (54 DAP), the flooding application had no effect on all root parameters. This shows that when entering the generative phase, tomato plants with application of flooding for 4 hours with a level of $50 \%$ have the same number of adventitious roots as other applications. The results of this study indicate that roots are important things that will be encouraged by plant growth and development to support the growth and development of fruit in the generative phase.

Tomato root in generative phase tries to maintain the function which has an important role in supplying food from the soil to the upper plants. This research showed in every level of flooding, the root still tries to play its function
Observation of tomato roots in generative phase was carried out once, at 55 days after planting (DAP). Root observation criteria were: total length of root, root length, adventitious root, root length binding to soil, root wet weight, root dry weight. The results of processed observational data can be seen in the Table 2 . in fulfilling its food needs from the inundated soil. This is in accordance with the theory according to Allard (2010) in Cahyono et. al,. (2014) which states that a plant has the ability needed for its growth in certain environmental conditions in this case is the absorption of nutrients for the plant itself to be able to grow properly.

\subsection{Effect of Flooding on the Growth and Development of Tomato Plants and Rooting of Pre-Harvest Phase Tomatoes}

Observation of tomato roots in pre-harvest phase was carried out once, at 69 days after planting (DAP). Root observation criteria were: total length of root, root length, adventitious root, root length binding to soil, root wet weight, root dry weight. The results of processed observational data can be seen in the Table 3 .

Table 3. Effect of Flooding on Total Root Length (LRV) of Tomato Plants, Tomato Plant Root Length, Number of Adventive Tomato Roots, Diameter of Soil binded by root, Wet Weight and Dry Weight of Tomato Plant Roots (69 DAP)

\begin{tabular}{|c|c|c|c|c|c|c|}
\hline \multirow{2}{*}{ Treatment } & $\begin{array}{l}\text { Total Root Length } \\
\text { (TRL) }\end{array}$ & $\begin{array}{l}\text { Tomato Plant } \\
\text { Root Length }\end{array}$ & $\begin{array}{c}\text { Number of } \\
\text { Adventive Roots }\end{array}$ & $\begin{array}{l}\text { The Diameter of } \\
\text { Soil binded by root }\end{array}$ & $\begin{array}{c}\text { Tomato Root Wet } \\
\text { Weight }\end{array}$ & $\begin{array}{c}\text { Tomato Root Dry } \\
\text { Weight }\end{array}$ \\
\hline & $\mathrm{cm}$ & $\mathrm{cm}$ & root & $\mathrm{cm}$ & g & G \\
\hline $\mathrm{J} 1$ & $3543.90 \mathrm{~b}$ & 41.25 & 13.50 & 12.50 & 24.30 & 4.63 \\
\hline $\mathrm{J} 2$ & 3963.30ab & 44.50 & 12.25 & 11.75 & 28.33 & 4.77 \\
\hline $\mathrm{J} 3$ & 3949.10ab & 41.75 & 11.50 & 12.00 & 25.06 & 3.63 \\
\hline $\mathrm{J} 4$ & 3999.80a & 39.50 & 12.00 & 11.00 & 30.70 & 3.60 \\
\hline Sig. & * & ns & ns & ns & ns & Ns \\
\hline
\end{tabular}

Note : J1= 4 hours of 50\% flooding level; J2= 8 hours of 50\% flooding level; J3= 4 hours of $100 \%$ flooding level; J4= 8 hours of $100 \%$ flooding level. 
Flooding treatment in the pre-harvest phase for two weeks from 56 DAP to 68 DAP with five times flooding application gives a influences on total root length, but did not give any influence to other parameter I.e. root lenght, number of adventitious roots, root length binding to soil diamater, root wet weight, root dry weight.

The results showed that close to harvest time, tomato plants responded to flooding stress, especially at the total root length. Flooding for 8 hours of $100 \%$ causes the tomato plant to have the longest root length. This is because tomato plants that are stress by flooding need to increase root growth longer. A higher total root length will ensure better nutrient uptake in plants and reach a wider area. The roots try to maintain their functions which have the most important role in supplying food from the soil, This is in accordance with the theory of Johnson (2015) which states that roots need oxygen to breathe and have normal cell activity. If there is residual oxygen used by roots in soil that is excess water or stagnant, the roots will stop functioning normally. Therefore, mineral nutrient uptake and water uptake are reduced or stopped in flood conditions (plants will wither because the roots are dead).

\subsection{Effect of Flooding on the Growth and Development of Tomato Plants and Rooting of Harvested Tomato Plants}

Observation of tomato roots in harvested phase was carried out once, at 83 days after planting (DAP). Root observation criteria were: total length of root, root length, adventitious root, root length binding to soil, root wet weight, root dry weight. The results of processed observational data can be seen in the Table 4 .

Table 4. Effect of Flooding on Total Root Length (LRV) of Tomato Plants, Tomato Plant Root Length, Number of Adventive Tomato Roots, The Diameter of Soil binded by root, Wet Weight and Dry Weight of Tomato Root Root after Flooding (83 DAP)

\begin{tabular}{|c|c|c|c|c|c|c|}
\hline Treatment & $\begin{array}{l}\text { Total Root Length } \\
\text { (TRL) }\end{array}$ & $\begin{array}{l}\text { Tomato Plant } \\
\text { Root Length }\end{array}$ & $\begin{array}{l}\text { Number of } \\
\text { Adventive } \\
\text { Roots }\end{array}$ & $\begin{array}{l}\text { The Diameter of } \\
\text { Soil binded by root }\end{array}$ & $\begin{array}{c}\text { Tomato Root Wet } \\
\text { Weight }\end{array}$ & $\begin{array}{c}\text { Tomato Root Dry } \\
\text { Weight }\end{array}$ \\
\hline & $\mathrm{cm}$ & $\mathrm{cm}$ & root & $\mathrm{cm}$ & g & G \\
\hline $\mathrm{J} 1$ & 5221.66 & 38.00 & 7.25 & 12.50 & $35.78 b$ & 7.96 \\
\hline $\mathrm{J} 2$ & 5560.50 & 41.75 & 7.25 & 11.25 & $46.90 \mathrm{a}$ & 5.93 \\
\hline $\mathrm{J} 3$ & 5565.02 & 39.25 & 7.75 & 11.75 & $52.62 \mathrm{a}$ & 5.99 \\
\hline $\mathrm{J} 4$ & 5794.25 & 37.75 & 7.50 & 10.00 & $35.17 b$ & 6.06 \\
\hline Sig. & ns & ns & ns & ns & * & Ns \\
\hline
\end{tabular}

Note : J1= 4 hours of 50\% flooding level; J2= 8 hours of 50\% flooding level; J3= 4 hours of $100 \%$ flooding level; J4= 8 hours of $100 \%$ flooding level.

Flooding condition in the harvested phase for two weeks from 70 DAP to 80 DAP with five times flooding application gives a variety of influences on Tomato Root Wet Weight.

The results showed that during the harvested phase, the roots of the tomato plant had grown and developed optimally. However, the condition of water stress will cause the roots during their growth to absorb water in the plant tissue which causes differences in the wet weight of the roots of tomato plants. Application of 4 hours of $100 \%$ flooding level and 8 hour of 50\% flooding level shows higher root wet weight compared to application of flooding 4 hours of $50 \%$ flooding level and 8 hours of $100 \%$ flooding level. This is due to a 4 hour of flooding level and 8 hour of 100\% flooding level level causing some of the root roots to be muffled when applied to flooding. Whereas in the other two applications, tomato plants will develop adaptations by serving the roots of flooding stress better, especially against the entry of water in root cell tissue. It was stated by $\mathrm{Wu}$ and Daniel (2000), Smith (2000) and Hyacinthe et al. (2015) that plant roots will modify the root cell walls of plants to prevent excessive entry of water into plant tissue.

\section{CONCLUSION}

Based on the results of research and discussion of giving flooding to each phase of growth and development of tomato plants especially its roots can be concluded that: In the vegetative phase, flooding simulation with a 4-hour time level of $50 \%$ flooding (J1) and flooding with 8 hours altitude $50 \%$ flooding (J2) in this treatment tomato plant roots can develop well, but still have a negative impact on the roots of tomatoes, while giving flooding with a time of 4 hours the level of $100 \%$ flooding (J3) and 8 hours the level of $100 \%$ flooding ( J4) has the highest negative impact, in the development of the roots of tomato plants. In the generative phase, the flooding simulation with a time of 4 hours at a level of $100 \%$ flooding (J3) and giving flooding time of 4 hours at a height level of $100 \%$ flooding (J4) has a negative impact so that the roots of tomato plants can develop well, while flooding with $450 \%$ flooding (J1) and 8\% 50\% flooding (J2) levels have the highest negative impact on tomato roots, so this treatment for the generative phase makes the roots of tomatoes not well developed. In the pre-harvest phase until the harvest phase the roots of tomato plants can grow and develop on giving flooding with an 8-hour level of $50 \%$ flooding (J2). 
While the provision of flooding with a time of 8 hours at an altitude level of $100 \%$ flooding (J4) has the worst effect on the growth and development of the roots of tomato plants.

\section{REFERENCES}

Armstrong, W. 1987. The Anatomical Characteristics of Roots and Plants Response to Soil Flooding. Departement of Plant Biology and Genetics, The University of Hull.

Bandi, AA, Sumono, Murir AP. 2014. Study of flood duration to the water quality and physical properties of Andosol soil and the Growth of Tomato (Lycopersicum esculentum Mill.)(Written in Indonesian language). Jurnal Rekayasa Pangan dan Pertanian Vol 2. Program Studi Keteknikan Pertanian, Fakultas Pertanian USU.

Besset, J., M. Genard, T. Girard, V. Serra, and C. Bussi. 2001. Effect of water stress applied during the final stage of rapid growth on peach tress (c. Big-Top). Jour. Scientia Horticulturae 91 (2001): 289-303.

Cahyono, B, Tripama B. 2014. The response of tomato plants to the application of bokashi fertilizer and plant spacing (Written in Indonesian language). Agritop Jurnal Ilmu-Ilmu Pertanian. Universitas Muhammadiyah. Jember.

Cahyono, B. 1998. Tomat Budidaya dan Analisis Usaha Tani. Penerbit Kanisius. Yogyakarta. Hal 65

Gould W. A. 1974. Tomato Production, Processing and Quality Evaluation. The Avi Publ. Co., Inc. USA. 445p.

Harjadi, SS. Yahya S, 1988. Fisiologi Stress Lingkungan IPB. Bogor.

Huang B, Johnson JW, NeSmith DS (1997) Responses to root-zone $\mathrm{CO}_{2}$ enrichment and hypoxia of wheat genotypes differing in waterlogging tolerance. Crop Science 37, 464-468

Hyacinthe Le Gall, Florian Philippe, Jean-Marc Domon, Françoise Gillet, Jérôme Pelloux and Catherine Rayon. 2015. Cell Wall Metabolism in Response to Abiotic Stress. Plants 2015, 4, 112-166; doi:10.3390/plants4010112

Kurniadinata OF, Poerwanto R, Efendi D, Wachjar A. 2016. Solving yellow sap contamination on mangosteen (Garcinia mangostana) by using $\mathrm{Ca} 2+$ and biopores (Written in Indonesian language). Jurnal Hortikultura Vol. 26 No 1, Fakultas Pertanian Institut Pertanian Bogor. Bogor.

Lu Y, Watanabe A, Kimura M . 2004. Contribution of plant photosynthates to dissolved organic carbon in a flooded rice soil. Biogeochemistry 71, 1-15.

Pezeshki SR, Pardue JH, Delaune RD (2006) Leaf gas exchange and growth of flood-tolerant and flood-sensitive tree species under low soil redox conditions. Tree Physiology 16, 453-458.

Pezeshki, SR. 2001. Wetland plant responses to soil flooding. Environmental and Experimental Botany 46, 299-312.

Rudich, J. And U. Luchinsky. 1986. The Tomato Crop. In: Atherton, J. G and J. Rudich (Eds.). Water economy. New York. Chapman and Hall.

Smith, A.L. 2000. Root Methods, A Handbook. CAB International. Wellingford. UK.

Yajun Wu Daniel J. Cosgrove. 2000. Adaptation of roots to low water potentials by changes in cell wall extensibility and cell wall proteins. ournal of Experimental Botany, Volume 51, Issue 350, 1 September 2000, Pages 1543-1553. 